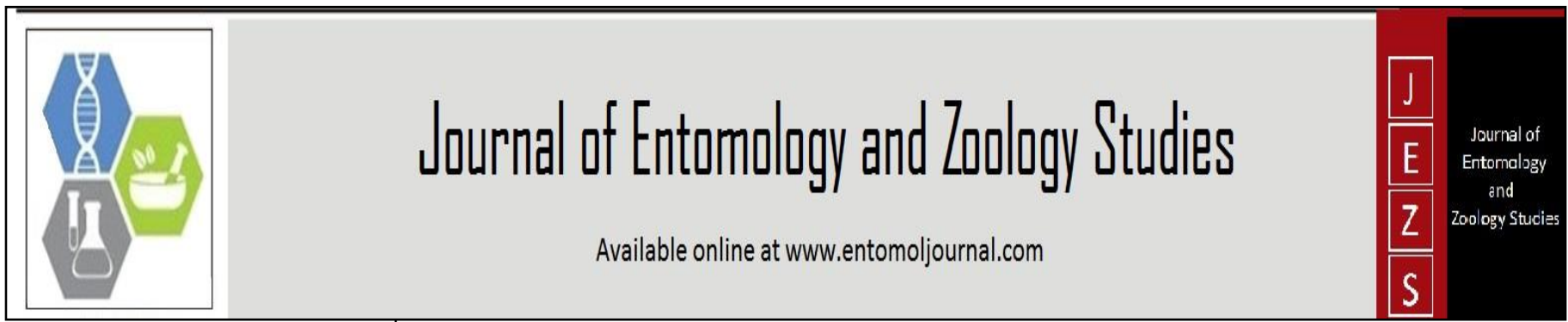

E-ISSN: 2320-7078

P-ISSN: 2349-6800

www.entomoljournal.com

JEZS 2020; 8(5): 1508-1511

(C) $2020 \mathrm{JEZS}$

Received: 18-06-2020

Accepted: 16-08-2020

\section{Nadeya Khaliq}

Division of Entomology, Faculty

of Agriculture, Sher-e-Kashmir

University of Agricultural

Sciences \& Technology of

Jammu, Chatha, Jammu,

Jammu and Kashmir, India

Uma Shankar

Division of Entomology, Faculty of Agriculture, Sher-e-Kashmi

University of Agricultural

Sciences \& Technology of

Jammu, Chatha, Jammu,

Jammu and Kashmir, India
Corresponding Author:

Nadeya Khaliq

Division of Entomology, Faculty of Agriculture, Sher-e-Kashmir

University of Agricultural

Sciences \& Technology of

Jammu, Chatha, Jammu,

Jammu and Kashmir, India

\title{
Population dynamics of tomato leaf miner, Liriomyza trifolii Burges on tomato, Solanum lycopersicum $\mathrm{L}$.
}

\section{Nadeya Khaliq and Uma Shankar}

DOI: https://doi.org/10.22271/j.ento.2020.v8.i5u.7714

\section{Abstract}

An experiment was conducted to study the effect of abiotic factors on the populations of leaf miner, Liriomyza trifolii Burges on Tomato, (Solanum lycopersicum L.) during 2017 and 2018 at research farm of Sher-e-Kashmir University of Agricultural Sciences and Technology of Jammu, Chatha. The results of the investigation on population dynamics of leaf miner, L. trifolii in relation to abiotic factors of both the years revealed that the pest commenced from $10^{\text {th }}$ standard week, which remained till 26th standard week with its peak activity during 15 th standard week. The correlation studies indicated highly significant and positive association between population of leaf miner and maximum temperature $(0.120 * *)$, while, significant and negative correlation with relative humidity evening $\left(-0.488^{*}\right)$ and rainfall $\left(-0.538^{*}\right)$. The overall impact of abiotic factors on population build-up of leaf miner was 80.30 per cent.

Keywords: Leaf miner, population dynamics, correlation, abiotic factors, tomato, Solanum lycopersicum

\section{Introduction}

Tomato is an important vegetable crop all over the world and it is good in vitamins. Tomato rank third in priority after potato and onion in India but ranks second after potato in the world. India rank second in the area as well as in production of tomato. In India it occupies an area of 808.5 thousand hectare with production of 19696.9 thousand metric tonnes and productivity of 24.4 metric tonnes per hectare ${ }^{[1]}$. In Jammu and Kashmir, it was grown in an area of 3.58 thousand hectares with the production of 88.09 thousand metric tonnes. Tomato production in the current year is likely to be around 194 lakh tones as against 207 lakh tones in 2016-2017 which is about $3 \%$ higher than the last 5 year's average production. In Jammu and Kashmir, it was grown in an area of 801 hectares with the production of 22337 million tonnes in 2017-18 [2]. The major constraint in the successful production of tomato in Jammu region is the attack of several insect-pests and diseases at different growth stages of the plant which cause considerable damage resulting into the low production. Within the pests complex of tomatoes, leaf miners Liriomyza spp. (Diptera: Agromyzidae) cause substantial damage in tomato production [3]. According to), the major insect pests attacking tomato are fruit borer [Helicoverpa armigera (Hubner) Hardwick] army worm (Spodoptera exigua Hubner) whitefly (Bemisia tabaci Gennadius); leaf miner (Liriomyza trifolii Burgess) and spider mites (Tetranychus cinnabarinus Boisdual). Of these, leaf miner, L. trifolii (Agromyzidae: Diptera) has been found causing serious damage since last many years ${ }^{[4]}$. Leaf miner infestation is increasing every year at the alarming rate. This pest reduced the yield and fruit quality by direct feeding ${ }^{[5,6]}$. The estimated loss due to infestation of $L$. trifolii was $46-70$ per cent loss to tomato seedlings. ${ }^{[7]} 90$ per cent loss to tomato foliage ${ }^{[8]}$ and 70 per cent loss of tomato yield ${ }^{[9]}$.

In view of the economic importance of tomato cultivation in Jammu and the magnitudes of the damage caused by the leaf miners, it becomes imperative to keep continuous vigil on the population dynamics of leaf miners. Therefore, keeping in mind the economic importance of the crop and the magnitude of the damage caused by the leaf miners, the study has been proposed. 


\section{Materials and Methods}

An experiment was conducted to study the effect of abiotic factors on the population dynamics of leaf miner, L. trifolii on Tomato, Solanum lycopersicum during 2017 to 2018 at research farm of Sher-e-Kashmir University of Agricultural Sciences and Technology of Jammu Chatha. All the recommended agronomic practices were followed to raise the crop except plant protection measures, which enable the buildup of insect pests and their natural enemies in a pesticides free environment.

The variety Saksham was raised in randomized complete block design with in experimental plot of $5 \times 3 \mathrm{~m}^{2}$ with $100 \times$ $100 \mathrm{cms}$ spacing to record the Population dynamics of tomato leaf miner in relation to abiotic factors and their natural enemies during the crop season.

Weekly observations were recorded from 5 randomly selected plants. With a view to study the impact of different abiotic factors on pest incidence, a simple correlation between population of pest and abiotic factors was worked out using Statistical Package for the Social Sciences (SPSS 16.0) software. Correlation analysis with various abiotic factors of the environment and the statistical analysis was worked out.

\subsection{Regression model}

The effect of various environmental factors under study on population of leaf miner on tomato was estimated by using multiple linear regression analyses with the prediction equations given as:

Est. $Y_{1}=a+b_{1} X_{1}+b_{2} X_{2}+b_{3} X_{3}+b_{4} X_{4}+b_{5} X_{5}+b_{6} X_{6}+b_{7}$ $\mathrm{X}_{7}$

Where, $Y_{1}$ mean leaf miner population, ' $a$ ' is the constant (intercept) and $b_{1}$ to $b_{7}$ are the estimated regression coefficient associated with $\mathrm{X}_{1}$ to $\mathrm{X}_{7}$, respectively.

\section{Results}

Population dynamics of leaf miner on tomato in relation to abiotic factors at research farm of Sher-e-Kashmir University of Agricultural Sciences and Technology of Jammu Chatha during 2017 and 2018. It is evident that incidence of leaf miner population was observed from 10 th to $25^{\text {th }}$ standard meteorological week (SW) in both cropping season 2017 and 2018 (Table 1). The result showed that the leaf miner population was first observed in 10th SW (0.83 leaf miner/plant) when mean temperature (maximum and minimum), relative humidity (morning and evening), sunshine, rainfall, and wind speed during the period were recorded to be $24.4{ }^{\circ} \mathrm{C}, 9.25^{\circ} \mathrm{C}, 86$ and 48per cent,6.75, 19.2 $\mathrm{mm}, 2.9 \mathrm{~km} / \mathrm{hr}$, respectively. The leaf miner population increases in $11^{\text {th }} \mathrm{SW}$ (1.33 leaf miner/plant) when mean temperature (maximum and minimum), relative humidity (morning and evening), sunshine, rainfall, and wind speed during the period were recorded to be $26.0^{\circ} \mathrm{C}, 9.45{ }^{\circ} \mathrm{C}, 81$ and 41 per cent, $6.75,1 \mathrm{~mm}, 2.4 \mathrm{~km} / \mathrm{hr}$, respectively and reached its peak (6.60 leaf miner/plant) during 15th SW, when mean temperature (maximum and minimum), relative humidity (morning and evening), sunshine, rainfall, and wind speed during the period were recorded to be $32.5^{\circ} \mathrm{C}, 14.1^{\circ} \mathrm{C}$, 74 and 34.5 per cent, $8.45,1.9 \mathrm{~mm}, 3.2 \mathrm{~km} / \mathrm{hr}$, respectively. Then declined in 17th SW (4.60 leaf miner/plant) and again increases in 19th SW (6.00 leaf miner/plant). Thereafter, leaf miner population declined trend was observed and population of leaf miner reached to ( 0.37 leaf miner per plant) during 26th SW, when mean temperature (maximum and minimum), relative humidity (morning and evening), sunshine, rainfall, and wind speed during the period were recorded to be 34.4 ${ }^{\circ} \mathrm{C}, 25.3{ }^{\circ} \mathrm{C}, 75.5$ and 55.7 per cent, $4.7,94.2 \mathrm{~mm}, 3.5 \mathrm{~km} / \mathrm{hr}$, respectively.

The effect of key abiotic factors on the incidence of tomato leaf miner was studied using correlation matrix. The correlation studies showed that the population of leaf miner population was observed to be positive highly significant with temperature (maximum) $\left(0.120^{* *}\right)$ and negative but significant correlation with relative humidity (evening) ($\left.0.488^{*}\right)$ and rainfall $\left(-0.538^{*}\right)$ and positive significant with sunshine $(0.496 *)$ whereas positive correlation with wind speed (0.338) and negative correlation with temperature (minimum) (-0.252) and relative humidity (morning) (-0.191). Table 2.

The value of multiple linear regression equations for tomato leaf miner was calculated to be $\mathrm{Y}=-46.736+1.634 \mathrm{X}_{1}-1.308$ $\mathrm{X}_{2}+0.202 \mathrm{X}_{3}-0.17 \quad \mathrm{X}_{4}-0.767 \quad \mathrm{X}_{5}+0.013 \quad \mathrm{X}_{6}+2.640 \mathrm{X}_{7}$. The corresponding correlation co-efficient of multiple determination $\left(\mathrm{R}^{2}\right)$ values worked out to be 0.803 was found statistically significant at $5 \%$ level of significance.

The overall impact of abiotic factors on population build-up of leaf miner was 80.30 per cent which reflects a positive correlation of leaf miner population with evening relative humidity, sunshine and rainfall negative correlation with other abiotic factors (Table 3).

\section{Discussion}

The present findings are in conformity with the findings obtained by Selvaraj et al. ${ }^{[10]}$ revealed that the pest $L$. trifolii on tomato (S. lycopersicum L.) was first appearance in 8th and 9th standard meteorological week (SMW) i.e. (February and March), attain peak population in 14th and 17th SMW (April), respectively. Whereas, Ulubilir and Yabas (2000) ${ }^{[11]}$ also more or less confirmed the results of the present investigation, who found that in tomato the adult population of leaf miner, L trifolii to be high during April and May, and decreasing in June. The adult population observed during autumn was at its peak in mid-November and then dropped down at the end of December.

Ashlata (2002) ${ }^{[12]}$ recorded that leaf infestation $(\%)$ by leaf miner and pest population on leaf miner was correlated with meteorological parameters; she found that both positively correlated with maximum temperature and sunshine hours and negatively correlated with relative humidity and minimum temperature on tomato crop. Whereas, Bagmare et al. (1995) [13] reported that the maximum temperature and sunshine hours had a positive correlation with the population of Liriomyza trifolii on tomato, whereas rainfall and relative humidity had negative association with the population of leaf miners. 
Table 1: Pooled data of two years on population dynamics of leaf miner, L. trifolii on Tomato

\begin{tabular}{|c|c|c|c|c|c|c|c|c|}
\hline \multirow{2}{*}{ Standard week } & \multirow{2}{*}{$\begin{array}{l}\text { Mean* leaf miner } \\
\text { population /plant }\end{array}$} & \multicolumn{2}{|c|}{ Temperature $\left({ }^{0} \mathrm{C}\right)$} & \multicolumn{2}{|c|}{ Relative humidity (\%) } & \multirow{2}{*}{ Sunshine } & \multirow{2}{*}{$\begin{array}{c}\text { Rainfall } \\
\text { (mm) }\end{array}$} & \multirow{2}{*}{$\begin{array}{c}\text { Wind speed } \\
\left(\mathrm{kmh}^{-1}\right)\end{array}$} \\
\hline & & Maximum & Minimum & Morning & Evening & & & \\
\hline 10 & 0.83 & 24.4 & 9.25 & 86 & 48 & 6.75 & 19.2 & 2.9 \\
\hline 11 & 1.33 & 26.0 & 9.45 & 81 & 41 & 6.75 & 1 & 2.4 \\
\hline 12 & 3.29 & 28.5 & 12.4 & 83 & 44 & 6.1 & 0.55 & 2.5 \\
\hline 13 & 3.99 & 32.7 & 14.6 & 84 & 39 & 8.05 & 0 & 2.0 \\
\hline 14 & 5.15 & 31.7 & 16.05 & 78 & 40 & 4.7 & 9.9 & 2.6 \\
\hline 15 & 6.60 & 32.5 & 14.1 & 74 & 34.5 & 8.45 & 1.9 & 3.2 \\
\hline 16 & 5.98 & 34.6 & 18.0 & 69.5 & 37 & 7.95 & 2.2 & 3.8 \\
\hline 17 & 4.60 & 36.8 & 16.9 & 63.5 & 24 & 9.6 & 0.9 & 2.5 \\
\hline 18 & 5.53 & 36.3 & 18.3 & 58 & 27 & 9.15 & 0.5 & 4.7 \\
\hline 19 & 6.00 & 38.0 & 20.0 & 58.5 & 28 & 8.25 & 0.35 & 3.9 \\
\hline 20 & 5.27 & 37.5 & 21.0 & 56 & 26.5 & 6.2 & 0.7 & 4.0 \\
\hline 21 & 3.05 & 39.5 & 20.15 & 54.5 & 24 & 8.65 & 1.4 & 2.7 \\
\hline 22 & 2.06 & 40.2 & 22.7 & 52.5 & 23.5 & 9.35 & 3.8 & 3.9 \\
\hline 23 & 1.38 & 39.0 & 25.7 & 66.5 & 33.5 & 6.25 & 20.7 & 3.6 \\
\hline 24 & 0.75 & 37.9 & 24.5 & 58.6 & 32.5 & 6.7 & 2.4 & 3.3 \\
\hline 25 & 0.25 & 36.5 & 23.9 & 71.1 & 46.7 & 3.4 & 34 & 2.6 \\
\hline 26 & 0.37 & 34.4 & 25.3 & 75.5 & 55.7 & 4.7 & 94.2 & 3.5 \\
\hline Range & $0.83-6.60$ & $24.4-40.2$ & $9.25-25.7$ & $66.5-86$ & $33.5-55.7$ & $3.4-9.35$ & $0.0-94.2$ & $2-4.7$ \\
\hline Mean & 3.32 & 34.5 & 18.37 & 68.8 & 35.5 & 7.11 & 11.39 & 3.20 \\
\hline $\operatorname{S.Em}( \pm)$ & 0.54 & 1.12 & 1.27 & 2.73 & 2.31 & 0.43 & 5.67 & 0.17 \\
\hline
\end{tabular}

*Mean of five plants

Table 2: Correlation coefficients and regression model between leaf miner population in relation to abiotic factors

\begin{tabular}{|c|c|c|c|c|c|c|c|}
\hline \multirow{2}{*}{ Pest } & Temperature ( $\left.{ }^{\circ} \mathbf{c}\right)$ & Relative humidity (\%) & Sunshine & Rainfall (mm) & Wind speed (kmh $^{-1}$ ) \\
\cline { 2 - 8 } & Maximum & Minimum & Morning & Evening & & & 0.338 \\
\hline Population of Leaf miner & $0.120^{* *}$ & -0.252 & -0.191 & $-0.488^{*}$ & $0.496^{*}$ & $-0.538^{*}$ & \\
\hline \multicolumn{8}{|c|}{$*$ Significant at the 0.01 level } \\
\hline \multicolumn{8}{|c|}{ Significant at the 0.05 level }
\end{tabular}

Table 3: Regression equations and co-efficient of multiple determination (R2) of leaf miner in relation to abiotic factors (pooled)

\begin{tabular}{|c|c|c|c|c|}
\hline Insect pest & Regression linear equations of leaf miner & $\begin{array}{c}\text { Correlation } \\
\text { co-efficient }(\mathbf{r})\end{array}$ & $\begin{array}{c}\text { Co-efficient of } \\
\text { determination }\left(\mathbf{R}^{2}\right)\end{array}$ & $\begin{array}{c}\text { Co-efficient of } \\
\text { Variation }(\%)\end{array}$ \\
\hline $\begin{array}{c}\text { Leaf miner } \\
\text { population }\end{array}$ & $\mathrm{X}_{1}-1.308 \mathrm{X}_{2}+.202 \mathrm{X}_{3}-0.17 \mathrm{X}_{4}-0.767 \mathrm{X}_{5}+0.013 \mathrm{X}_{6}+2.640 \mathrm{X}_{7}$ & 0.896 & 0.803 & 80.30 \\
\hline
\end{tabular}

Where,

$\mathrm{Y}=$ Mean No. of Leaf miner population/plant $\mathrm{X} 4=\mathrm{RH}$ Evening
$\mathrm{X} 1=$ Max Temp.

$\mathrm{X} 2=\mathrm{Min}$ Temp.

X3=RH Morning
$\mathrm{X} 5=$ Sunshine

X6=Rainfall

$\mathrm{X} 7=$ Wind speed $\mathrm{kmh}^{-1}$

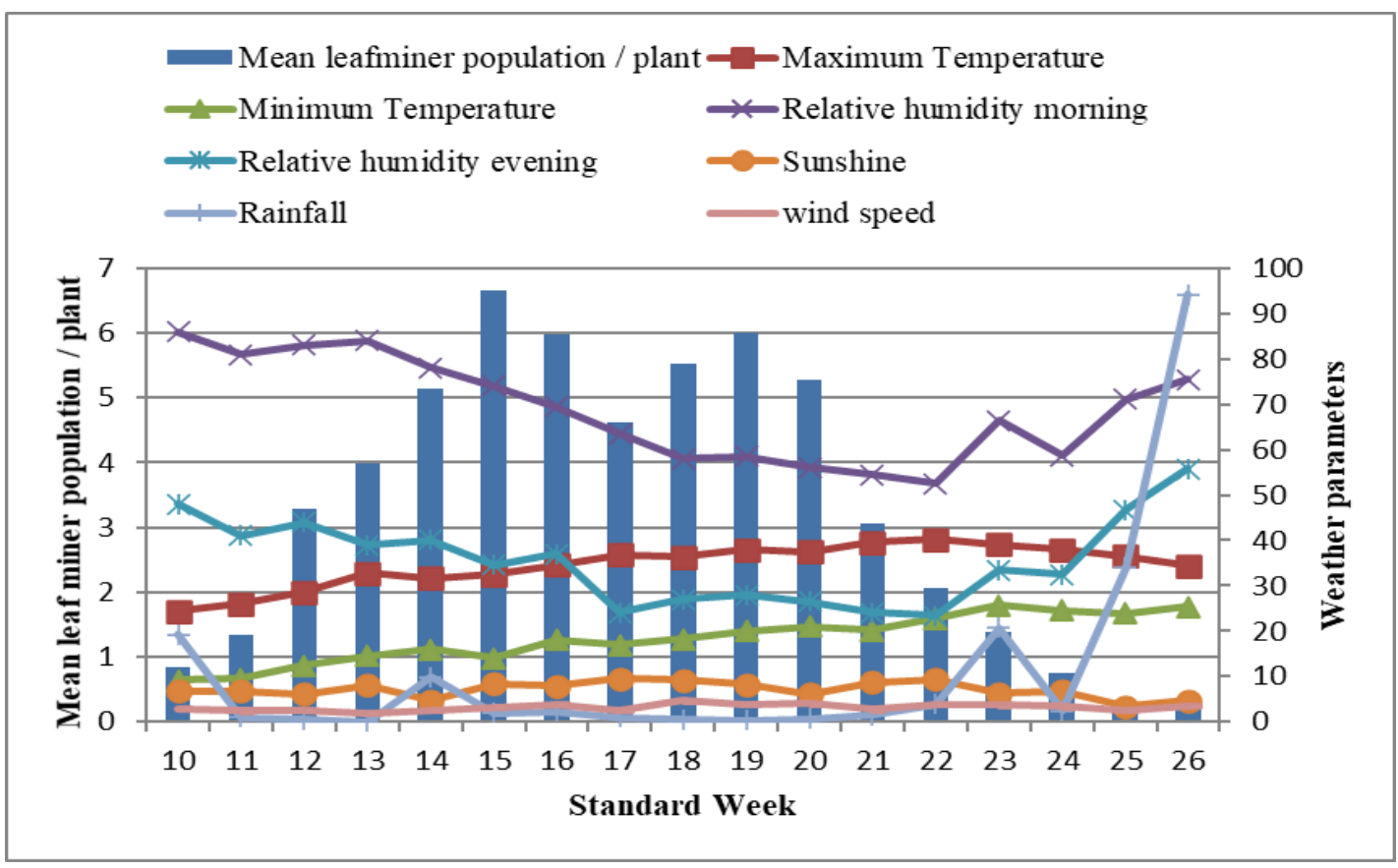

Fig 1: Population dynamics of leaf miner, L. trifolii on Tomato (pooled) 


\section{Conclusion}

Tomato is a commercial crop for getting higher remuneration for the farming community. Since the sowing of seeds in nursery to harvesting of fruits, the crops have been ravaged by the magnitude of insect-pest. Among which leaf miners infestations are of major concern. In this context, the present study drew the conclusion that infestation based on mines (6.60 leaf miner/plant) attained the highest population during $15^{\text {th }} \mathrm{S} \mathrm{W}$. Coupled with the abiotic factors, the infestation and degree of damage enhances on crops and thereby reduction in yield potential. The present study will help in formulation of integrated pest management practices to mitigate the damage caused by leaf miners on right time.

\section{References}

1. Indian Horticulture Database. National Horticulture Board, Ministry of agriculture Government of India, Gurgaon, India. 2016-17.

2. Area Production Data - Directorate of Horticulture Kashmir, India. 2017-18.

3. Waterhouse DF, Norris KR. Liriomyza species (Diptera: Agromyzidae) leafminers, In: Waterhouse DF, Norris KR (eds). Biological control: Pacific prospects. Inkata Press,

4. Melbourne, Australia.1987, 159-176.

5. Nagaraju N, Venkatesh HM, Warburton H, Muniyappa V, Chancellor CB, Colvin J. Farmer's perceptions and practices for managing tomato leaf curl virus disease in southern India. International Journal of Pest Management. 2002; 48(4):333-338.

6. Bethke JA, Parrella MP. Effect of Tomato cultivar and fertilizer regime on the survival of Liriomyza trifolli (Diptera: Agromizidae) Entomologia Experimentalis et Applicata. 1985; 39:149-154.

7. Parrella MP. Biology of Liriomyza. Annual Review of Entomology, 1987; 32:201-224.

8. Pohronezny L, Waddill VH, Schuster DJ, Sonoda RM. Integrated pest management for Florida tomatoes. Plant Disease. 1986; 70:96-102.

9. Johnson MW, Welter SC, Toscano NC, Ting IP, Trumble JT. Reduction of tomato leaflet photosynthesis rates by mining activity of Liriomyza sativae (Diptera: Agromyzidae). Journal of Economic Entomology. 1983; 76:1061-1063.

10. Zoebisch TC, Schuster DJ, Gilreath JP. Liriomyza trifolii: Oviposition and development in foliage of tomato and common weed hosts. Florida Entomologist. 1984; 67(2):250-254.

11. Selvaraj S, Bisht RS, Ganeshamoorthi P. Seasonal Incidence of American Serpentine Leaf miner Liriomyza trifolii (Burgess), on Tomato at Pantnagar, Uttarakhand.

12. International Journal of Agriculture Sciences. 2016; 8(38):1777-1779.

13. Ulubilir A, Yabas C. Studies on population development of leafminer (Liriomyza spp.) and parasitation situation. Bulletin-OILB/SROP, France. 2000; 23(1):151-156

14. Ashlata. Seasonal activity and bioefficacy of some ecofriendly insecticide against the serpentine leaf miner Liriomyza trifolii. M.Sc. (Ag.) Thesis JNKVV. Jabalpur 2002

15. Bagmare A, Sharma D, Gupta A. Effect of weather parameters on the population build-up of various leaf miner species infesting different host plants. Crop Research. 1995; 10(3):344-395. 